\title{
КОНСТРУКТИВНІ НАСЛІДКИ КОНФЛІКТУ СУБ'ЄКТИВНОГО ХАРАКТЕРУ
}

\begin{abstract}
Л.А. Білоконенко
Останні десятиліття фактично створили моду на вивчення конфлікту. В різних галузях науки досліджується теорія та практика конфлікту, а життя ілюструє сталість породження одними жорстокими протиборствами інших. Наміри створити модель безконфліктного суспільства виявилися марними. Тож основна ознака конфлікту - повсякденна реальність - не викликає жодного сумніву: існування людського суспільства базується на протиріччях та консенсусах.

Досить стабільною є думка, що конфлікт - це негативне явище, яке має лише деструктивний характер. Та у конфліктології існує й інша точка зору: кожна конфліктна ситуація чи конфлікт мають свої позитивні наслідки.

М. Дойч зазначає, що наукова проблема конфлікту полягає «у можливості відповісти на питання: за яких умов швидше виникає жива полеміка, ніж смертельна суперечка?» [5, с.174], та вважає, що необхідний аналіз поведінки особи, типу проблеми, бажання вирішити іï конструктивно, розгляд соціокультурного контексту та процесів, які призводять до експансії конфлікту. М. Дойч визначає також типи навичок, які дозволяють третій стороні конструктивно вирішити суперечку [5, с. 173-198].

Позитивні наслідки соціального конфлікту, які характерні для відкритих соціальних структур, описано Г.І. Козирєвим. Зокрема, соціологом зазначено, що конфлікт сприяє суспільному розвитку, стабілізує стосунки у групі та між групами; надає суспільству динамічності, заохочує до творчості та інновацій, допомагає прогресу, надає інформацію про навколишнє соціальне середовище, допомагає виявити друзів
\end{abstract}

Актуальні проблеми духовності 
чи ворогів; проявляє позиції, інтереси, цілі опонентів тощо [8, с. 20-21].

Психолог Н.В.Гришина поділяе сучасну точку зору стосовно подвійної природи конфлікту, розглядає позитивні наслідки саме соціального конфлікту, визначає їх з позиції «живої людини»: конфлікт джерело розвитку інтелектуальних здібностей особи, яке стимулює iï до активності. Він є сигналом до змін, який визначає, що щось не гаразд в самій людині чи в її стосунках з іншими людьми. Конфлікт - можливість зближення опонентів, розрядки та ломки конфліктних стосунків, на місці яких виникають нові взаємовідносини та нові поняття $[4$, с. $67-70]$. Визнаючи справедливість висновків Н.В. Гришиної, зазначимо, що вони мають лише загальний характер та не спрямовані на характеристику наслідків конфліктів за суб'єктами взаємодії.

А.Я. Анцупов та А.І. Шапілов звертають увагу на той факт, що конфлікт може бути деструктивним та конструктивним одночасно (на різних етапах проходження) [1, с. 273-275]. Описано конструктивні функції для конфліктантів: усуваються повністю чи частково протиріччя, глибше оцінюються індивідуально-психологічні особливості людей, послаблюється психологічна напруга; конфлікт стає джерелом розвитку

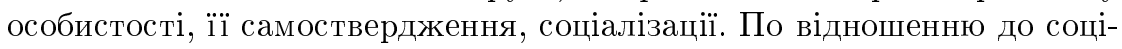
уму конструктивним конфлікт є тому, що він виступає як засіб активізації соціального життя, висвітлює невирішені проблеми в діяльності групи, колективу. Міжособистісні конфлікти в організаціях позитивно впливають на ефективність спільної діяльності; створюють нові сприятливі умови; виконують функцію згрупування колективу перед труднощами, оптимізують міжособистісні стосунки [1, с. 279-283]. Разом з тим, автори не описують конструктивні відмінності конфлікту саме суб'єктивного характеру, оперуючи лише рамками групи, колективу, організації. Роботи інших науковців (див. напр. [6], [7], [9], [10]) нової інформації із зазначеної проблеми не подають.

Звернемося до дії розвитку конфлікту, яка базується на чотирьох групах факторів та причин: об'єктивних, організаційних, соціальнопсихологічних та особистісних $[1$, с. 231-236]. Перші дві групи мають об'єктивний характер, третя та четверта-суб'єктивний. Розуміння об'єктивного та суб'єктивного характеру причин $\epsilon$ необхідним при визначенні способів попередження та оптимальної стратегії поведінки людини у типових конфліктах. До об'єктивних причин відносяться обставини соціальної взаємодії людей, які призвели до зіткнення їх інтересів, поглядів, установок і т. п. До суб'єктивних - індивідуальні психологічні особливості опонентів, котрі у передконфліктній ситуації мають можливість обрати саме конфліктне чи неконфліктне її вирі- 
шення.

Кожен конфлікт має і об'єктивний, і суб'єктивний характер. Але наявність об'єктивних причин не $є$ обов'язковою для прояву суб'єктивних: може бути обране і неконфліктне вирішення ситуації. Та соціально-економічні умови сучасного життя, на жаль, формують нестійку до конфлікту особистість, яка захищає власні інтереси, направлена на владу, силу, авторитет, задоволення власних потреб та досить часто має психологічну невмотивованість вчинків. Разом з тим, опоненти усвідомлюють, що конфлікт «створює соціальну напругу та призводить до руйнування соціальної системи» [7, с. 27]. Тому сторони, навіть опинившись в епіцентрі конфліктної взаємодії, розуміють необхідність її вирішення.

За думкою С.М. Ємельянова [7, с. 27-28], в основі деструктивних конфліктів, які є негативними за своїми наслідками, знаходяться саме суб'єктивні причини, тобто соціально-психологічні та особистісні. А в основі конструктивних конфліктів, які мають позитивні і негативні наслідки, - об'єктивні причини. Узагальнимо: конфлікт на основі суб'єктивних причин має лише негативні наслідки, на основі об'єктивних - негативні і позитивні наслідки. Але чому суб'єктивні причини мають лише негативний результат?

Отже, метою нашого дослідження є: вивчити та описати конструктивні наслідки конфлікту суб'єктивного характеру. Для аналізу обрано три види конфліктів за суб'єктами взаємодії: внутрішньоособистісний, міжособистісний та внутрішньогруповий - ті, в яких конфліктантом виступає конкретний суб'єкт. Адже первісною ознакою конфлікту $\epsilon$ те, що він має «людське обличчя» (виняток-зооконфлікти). Мало того, індивід-не просто носій конфлікту, він має свідомість, волю, активність до дій. Але основне - він має вибір.

Внутрішньоособистісний конфлікт (далі ВОК) - це особливий вид конфлікту, який виявляє протинаправлені сили, котрі характеризують потреби, бажання, можливості, цінності, інтереси суб'єкту. ВОК змушує «зробити вибір між тенденціями: позитивною та позитивною, позитивною та негативною, негативною та негативною» $[1$, с. 315]. Особливим ВОК є через те, що він не має звичних елементів структури: опонента (хоча може бути самоопонування), групи підтримки (хоча можливі «радники»). ВОК має складності з визначенням предмету суперечки, який проявляє реальні чи уявні проблеми. Суб'єкт може переживати уявну проблему важче ніж реальну або, навпаки, утаювати складне протиборство. Можливе ненавмисне приховування стану конфлікту від оточуючих. Шо стосується об'єкту конфлікту, то у ВОК 
він може бути присутнім чи відсутнім. У BOK можлива специфічна тенденція вибору між позитивним та позитивним виходом. Варто звернути увагу на перебіг BOK: можливий психологічний стан депресії, страху, неврозу, стресу, суӥцидальний настрій, формування комплексу неповноцінності та гальмування розвитку особистості.

Звернемося до основних видів ВОК та опишемо їх наслідки. Конфліктологи виділяють три типи BOK ([1, с. 318-320], [4, с. 80-96]). Перший тип - мотиваційний, який виникає через боротьбу мотивів. Його перший вид-вибір між позитивним та позитивним. Початково ніби не містить негативізму, але виходи з нього є взаємовиключними явищами, тому вибір обов'язковий. Подібна ситуація може призвести до драматизму, якщо особа має обирати між дорогими для неї людьми чи важливими і необхідними реаліями. Не даремно народна мудрість застерігає: від добра добра не шукають.

Другий вид - вибір між негативним та негативним. На перший погляд подібний ВОК має лише деструктивний характер: щоб не обрав суб'єкт - це не є привабливим. Але особа обирає «менше зло», фактично уникаючи більшого. Третій вид-вибір між позитивним і негативним. Ситуація ніби нескладна: обрати те, що є позитивним. Але в житті складаються ситуації, коли важко визначити, що є кращим. Зважуючи, що обрати, людина нервує, болісно реагує на ситуацію i, як результат, не тільки немотивований вибір, а і постійний стан сумніву, пригнічення.

Та мотиваційні конфлікти мають і позитивний характер. Несумісні позитивні чи негативні тенденції, які мають одночасну силу, змушують особу обирати більш значуще і поступово реалізувати обране. Причому не важливо: чи правильним є вибір. Суб'єкт має сам з собою компроміс: частково чимось поступається, приймає тимчасове рішення, відступає перед загрозою втратити більше. Інші стратегії виходу 3 цього конфлікту неможливі. Вибір між негативним та позитивним, перш за все, впливає на формування вміння аналізувати, рішучість та стійкість поведінки. Особа ніби співробітничає сама з собою через важливість рішення, яке сама і приймає. Подібна співпраця має і елементи поступки самій собі, вона дає шанс зберегти наявне, не зазнати шкоди, не втратити більше, ніж придбати. Вважаємо, що даний тип конфлікту впливає на становлення характеру людини.

Когнітивний тип конфліктів визначає зіткнення несумісних уявлень (теорія описана Л. Фестінгером). ВОК цього виду виникають не через протиріччя між двома системами, а через необхідність обирати. Дві суперечні думки створюють психологічну напругу, дискомфорт, 
які особа намагається спростити чи уникнути їх. Поступово рішення приймається, але впевненості у виборі немає. Суб'єкт починає або «умовляти» сам себе, що все обране $є$ правильним, або через певний час змінює рішення, знову переконуючи себе, що цей крок $є$ кращим. Деструктивізм цього конфлікту фактично проявляється лише через психологічні переживання людини, особливо коли вибір пов'язаний зі складними чи важливими обставинами. Але ж це вибір самої особи! Конструктивізм когнітивних ВОК полягає у необхідності проаналізувати ситуацію, переглянути своє ставлення до неї. Особа постає перед завданням змінити свою систему судження, своє ставлення до себе чи до оточуючих. Подібні «метання» суб'єкту супроводжуються емоційними переживаннями, але захисні механізми організму змушують людину змінитися, і як результат-поступове знаття психологічної напруги.

Ролевий тип конфліктів пов'язаний з переживаннями особи через неможливість одночасної реалізації кількох ролей, а також з нерозумінням вимог до виконання певної ролі. У психології описано два основні види ролевих конфліктів. Перший - «я-роль» (описаний В. Мерліном). Проблема виникає через протиріччя між вимогами до певної ролі та можливостями самої особи. У суб'єкта є уявлення про те, як має «виконуватися» певна роль (дитини, батька, чоловіка, підлеглого, керівника тощо). Але людина досить часто або нездатна «виконувати» роль саме так, як розуміє її суспільство чи сама особа; або виконує її правильно, але ця «правильність» не відповідає внутрішнім переконанням особи. У будь-якому випадку виникає ВОК: «знаю як, але не можу» та «виконую правильно, але мені це не подобається». Другий вид-міжролеві конфлікти. Виникають при наявності різних ролей особи, які несумісні. У суспільстві суб'єкт виконує кілька ролей, частина з яких досить просто поєднується, особливо сімейного плану: батька-чоловіка, матеpi-дружини, дружини-невістки, сина-батька і т. п. Особа намагається владнати свої ролеві позиції і у професійній сфері, але саме тут непоодинокі випадки розладу. Часто «поєднання» ролей призводить до серйозної психологічної проблеми. Подібний ВОК не тільки загрожуе ефективній діяльності особи, не лише призводить до деструктивізму міжособистісних стосунків (адже роль має відношення і до оточуючих), але і загрожує здоров'ю, життю людини.

Разом з тим ролеві конфлікти можуть мати і конструктивний характер. Вид «я-роль» змушує саму людину змінитися: якщо «я знаю як, але не можу», то яка необхідність ламати себе? Віднайдеться роль ідеальна для конкретної людини. Якщо «виконую роль правильно, але 
вона мені не подобається», яка необхідність псувати собі життя, відчувати себе нещасним? Не дарма говорять: «людина на своєму місці», тобто із збалансованим відчуттям: знаю, вмію, подобається. У випадку неможливості кардинальних змін особа може вирішити цей ВОК компромісом: послабити вимоги до ролі (адже вимоги створюють самі люди!) Вид міжролевих конфліктів вимагає змін у оточенні особи: якщо ролі є несумісні, треба або обрати одну з них, або знизити жорсткість вимог до них. Досить реальним є відхід від вирішення проблеми, що дає певний час для роздумів про подальші дії-і це плюс; або поступка, в результаті якої певна ролева поведінка зникає. Людина залежить від думок та оцінок сім'ї, друзів, оточуючих. Чи буде комфортно особі у ролі, яку оточуючі не приймають?

Узагальнимо описані конструктивні наслідки ВОК у таблиці 1.

\begin{tabular}{|c|c|c|c|c|}
\hline $\begin{array}{c}\text { № } \\
\Pi / \Pi\end{array}$ & Тип ВОК & Вид ВОК & $\begin{array}{l}\text { Модель } \\
\text { вирішення } \\
\text { ВОК }\end{array}$ & $\begin{array}{l}\text { Конструктивні } \\
\text { наслідки } \\
\text { ВОК }\end{array}$ \\
\hline \multirow[t]{2}{*}{1.} & \multirow[t]{2}{*}{$\begin{array}{l}\text { Мотива- } \\
\text { ційні } \\
\text { конфлікти }\end{array}$} & $\begin{array}{l}\text { між позитив- } \\
\text { ним та пози- } \\
\text { тивним } \\
\text { між негатив- } \\
\text { ним та нега- } \\
\text { тивним }\end{array}$ & компроміс & $\begin{array}{l}\text { обирається більш зна- } \\
\text { чуще, обране реалізу- } \\
\text { ється } \\
\text { виробляється рішу- } \\
\text { чість та стійкість } \\
\text { поведінки }\end{array}$ \\
\hline & & $\begin{array}{l}\text { між } \\
\text { позитив- } \\
\text { ним та } \\
\text { тивним нега- }\end{array}$ & $\begin{array}{l}\text { співробіт- } \\
\text { ництво } \\
\text { поступка }\end{array}$ & $\begin{array}{l}\text { формується вміння } \\
\text { аналізувати } \\
\text { впливає на становлен- } \\
\text { ня характеру особи }\end{array}$ \\
\hline 2. & $\begin{array}{l}\text { Когнітивні } \\
\text { конфлікти }\end{array}$ & & поступка & $\begin{array}{l}\text { формується вміння } \\
\text { аналізувати } \\
\text { переглядається став- } \\
\text { лення до ситуації, до } \\
\text { себе, до оточуючих } \\
\text { змінюєтья система } \\
\text { судження }\end{array}$ \\
\hline \multirow[t]{2}{*}{3.} & \multirow[t]{2}{*}{$\begin{array}{l}\text { Ролеві } \\
\text { конфлікти }\end{array}$} & «я-роль» & $\begin{array}{l}\text { відхід } \\
\text { компроміс }\end{array}$ & $\begin{array}{l}\text { призводить до змін у } \\
\text { самій людині } \\
\text { відшукується відпо- } \\
\text { відна людині роль } \\
\text { послаблюються вимо- } \\
\text { ги до ролі }\end{array}$ \\
\hline & & міжролеві & $\begin{array}{l}\text { відхід } \\
\text { поступка }\end{array}$ & $\begin{array}{l}\text { призводить до змін у } \\
\text { оточенні людини } \\
\text { обирається найбільш } \\
\text { важлива роль }\end{array}$ \\
\hline
\end{tabular}

Таблиця 1. Конструктивні наслідки внутрішньоособистісного конфлікту 
Міжособистісний конфлікт (далі MOK) - це найбільш розповсюджений вид конфлікту, який виявляє зіткнення між особами в процесі їх взаємодії на основі протиборства різнонаправлених мотивів. Існує досить широка i, разом з тим, докладно подана система факторів та причин MOK [7, с.223]. Об'єктивні фактори (стабільні об'єктивні обставини, на які практично неможливо вплинути) створюють потенційне поле для конфлікту: «правила гри», правила поведінки, сталі суспільні стосунки, влада, управління, власність тощо. Безумовно, протистояння потреб особи та об'єктивних обставин створює незадоволення ситуацією. За описаною вище системою С.М. Ємельянова, конфлікти на основі об'єктивних обставин мають і позитивні, і негативні наслідки, які у конфліктології проаналізовані і тому не можуть бути метою нашого дослідження. Але MOK мають і суб'єктивні фактори та причини. По-перше, це фактор стосунків, який виявляє несумісність чи складність у взаємовідносинах осіб. Фактор спрацьовує в умовах прояву різних цінностей, цілей, інтересів, манери поведінки та спілкування, рівня освіти, життєвого досвіду тощо. По-друге, фактор поведінки: агресія, грубість, безтактність, егоїзм, недотримання обіцянок. Фактор цінностей-протилежність принципів поведінки: дисбаланс на основі релігійних, культурних, політичних, моральних цінностей, традицій, вірувань тощо. Четвертий фактор - інформаційний: неточні факти, дезінформація, плітки, ненадійне джерело, сторонні факти і т. п.

Зазначені суб'єктивні фактори виявляють складну структуру міжособистісного спілкування, адже вони формуються на основі індивідуальних особливостей людей. MOK можливі і між знайомими, і незнайомими людьми. Стереотипи, настрій, установка чи просто непорозуміння сприяють виникненню конфлікту. Не виникає сумніву, що зміст факторів різниться в залежності від сфери вияву МОК: колектив, сім'я, суспільство. Та кожна сфера вияву MOK має і деструктивні, і конструктивні функції, в тому числі на основі зазначених суб'єктивних факторів.

Деструктивні наслідки завжди очевидні, тому надовго залишаються у пам'яті. Можливо значну частину негативних наслідків МОK узагальнити. По-перше, деструкція проявляється у стосунках з опонентом, адже ворожість, ненависть блокують результативне вирішення суперечки. Для опонентів конфлікт стає причиною порушення психологічного стану, викликає стрес, емоційну напругу, погіршує здоров'я. По-друге, MOK у колективі негативно впливає на ефективність професійної діяльності. Навіть після розв'язання такого конфлікту не- 
обхідний певний час і для стабілізації стосунків, і для відновлення продуктивності праці. Але, на наш погляд, найскладніше деструкція МOK проявляється у впливі на особу. У людини, яка «пережила» конфлікт із втратами для себе, може надовго сформуватися невіра в добро, справедливість; може бути втрачена надія, віра в людей. Фактично, це стає перепоною для подальшого розвитку особистості.

Конструктивні позитивні наслідки залежать у MOK, як на нашу думку, від бажання опонентів вирішити конфлікт. За умови установки у хоча б однієї зі сторін вирішити проблему, у іншої з'являється можливість для примирення. Чим довше тривав конфлікт, тим менше у його наслідках позитиву.

У сфері прояву конфлікту - колектив позитивним може бути: перерозподіл ресурсів, зміна цілей діяльності; зміна позицій, ролі особи; визначення нового статусу учасників суперечки. По закінченні MOK у колективі повністю чи частково зникають попередні протиріччя. Подібні конфлікти визначають професійні якості працівників та помилки керівників. Особа «тестується» конфліктом на стійкість до стресів, психологічної напруги (нестійка у сутичці особа наступного разу подумає, чи брати участь у новому конфлікті). Парадоксально, але конфлікт, який провокує стрес та негативні емоції, завдяки саме їм знижує свою інтенсивність. Ще одна особливість: після конфлікту у більше ніж $15 \%$ конфліктантів стосунки стають кращими, ніж до нього (за А. Анцуповим). За умови перемоги у справедливому конфлікті особа підвищує свій авторитет, до неї краще ставляться, у неї є шанс стати лідером, отримати підвищення тощо.

Сфера вияву - суспільство (соціальні, державні, громадські установи, транспорт і т. п.). Позитив конфлікту: виявляє недоліки у функціонуванні соціальних, державних, громадських установ; визначає рівень психологічної, правової культури громадян i, як результат, вимагає втручання, впливу, змін. Сфера вияву впливу - сім'я: визначається дисгармонія у стосунках між батьками і дітьми, у подружжі, між подружжям та родичами. Виявляються індивідуально-психологічні особливості членів сім“ї та їх психолого-педагогічна культура. I навіть за умови розпаду сім’ї завжди буде сторона, для якої подібний вихід з конфлікту має позитивний сенс.

Внутрішньогруповий конфлікт (далі ВГК) досить складно вичленовується, адже конфліктантами є: окремі особи, сформовані у конфлікті угрупування, особа і інші члени групи і т. п. Тож «це стало обгрунтуванням для визнаної ... думки, що внутрішньогрупові конфлікти фактично не мають самостійної феноменології та приймають 
форму або міжособистісних, або міжгрупових конфліктів» [4, с. 113]. Але ВГК має ряд особливостей, які визначаються специфікою групи. Групи можуть бути різні: тимчасові та постійні, вільні та обов'язкові, відкриті та закриті, формальні та неформальні (за Г. Козирєвим). Разом з тим існує ряд спільних ознак: спілкування членів групи між собою на основі спільних інтересів, цілей чи діяльності; розподіл групових ролей; спільні норми, правила поведінки, установки; існування в часі та просторове місцезнаходження; групова ідентифікація. Зміни в групі, які не відповідають існуючим ознакам, протиборство між вимогами осіб незмінно призводять до конфлікту. Саме групові норми створюють основу суперечки: вони згуртовують групу і одночасно блокують будь-які нововведення. Членство людини у групі $\epsilon$ суперечним: людина не може без існування разом з іншими індивідами, але група, до якої входить особа, обмежує її свободу, право вибору, нав'язує «правила гри» та «роль». Та саме ці явища свідчать про позитивні функції ВГК. Л. Козер вважає, що чим тісніше згуртована група, тим важчий перебіг конфлікту, тим він інтенсивніший (див. [4, с. 114]). Без сумніву, група зі сталими, давніми нормами існування сприйматиме будь-яке нововведення як вороже, придушуватиме його. Але такі зміни активізують соціальне життя групи та людей, запобігають застою, розвивають групу, дають їй рух вперед. Це значний позитив.

ВГК виявляє невирішені проблеми у спільній діяльності групи. Це, перш за все, стосується осіб, діяльність яких не відповідає груповим очікуванням: цілі, цінності, інтереси, позиції не співпадають зі спільними. ВГК може призвести i до зміни статусу особи у групі, у тому числі на місце лідера. Реальним $є$ припинення непрофесійної діяльності (i по відношенню до рядового працівника, і до керівника). Тому ВГК в організаціях впливають на ефективність спільної діяльності, на стабілізацію статусно-ролевих позицій членів групи.

K. Кемпбелл зазначає позитив ВГК у згуртуванні при наявності спільного «зовнішнього ворога» групи [11]. Думка видається нам слушною, тим більше, що у ролі «ворога» може бути будь-яка об'єктивна реальність. Маючи об'єкт для протидії, група трансформується, змінюється ситуація, ведуться пошуки шляхів для встановлення знову рівноваги. ВГК також може виявити складність, недоречність, важкість у стосунках між індивідами, а це означає, що суперечка призведе до створення нових, сприятливих умов спілкування. Надзвичайно позитивною функцією ВГК, вважаємо, є зв'язок міри її конфліктності з мірою її розвитку та дотримання соціальних норм. Виявляючи протиріччя, конфлікт активізує опірність групи та формує прийнятні 
соціальні установки, які незмінно підвищують ефективність її діяльності.

Отже, конфлікт має двоїстий характер, що обумовлено відсутністю визнаної та описаної взаємодії деструктивних та конструктивних наслідків. Причиною такої невизначеності виступає сам конфлікт, який може бути одночасно і конструктивним, і деструктивним (для різних сторін), або по мірі розвитку міняє свій характер. Звернувшись до конфліктів суб'єктивного характеру, ми спробували виявити та описати їх конструктивізм, та нам довелося звертатися і до негативних наслідків, бо то є дві сторони одного явища.

До конструктивних наслідків ВОК нами віднесено: формування вміння обирати важливий факт, приймати важливе рішення та реалізувати обране; формувати вміння аналізувати ситуації, поведінку людей, переглядати своє ставлення до себе, до оточуючих, до життєвих реалій; визнання необхідності відшукувати своє місце в житті, свою «роль»; виробляти рішучість та стійкість поведінки. Звичайно, позитив ВОК виявиться лише за умови, що особа не зазнала психічних втрат, зберегла цілісність своєї свідомості і, головне, мала бажання вийти з конфлікту та зробити правильні висновки.

Позитивні наслідки МОK залежать від сфери впливу (колектив, суспільство, сім'я). Узагальнення нам видається таким: зменшуються чи Зникають виявлені протиріччя; опоненти кращу пізнають один одного, «тестуються» суперечкою; зменшується психологічна напруга (за будь-якого виходу 3 конфлікту); активізується життя особи (професійне, суспільне, сімейне). Конструктивізм MOK має реальний прояв i для сторони - переможця, і для переможеної сторони.

У ВГК конструктивний характер незмінно призводить до активізації опірності групи, підвищує ефективність її діяльності, запобігає застою, розвиває і рухає групу вперед. Такий вид конфлікту стає лакмусовим папером, котрий визначає: чи життєздатна, чи діюча, чи перспективна група. Отже, конфлікт суб'єктивного характеру не має «знищувати» людину. Фактично, відбувається нормальний процес, який необхідний для життєдіяльності та взаємодії особи із собою та іншими індивідами. Тож конфлікт - це майже добре!

\section{1 Бібліографія}

[1] Анцупов А.Я., Шапилов А.И. Конфликтология.- М.: ЮНИТИ, 2004. 
[2] Аниупов А.Я., Шапилов А.И. Конфликтология в схемах и комментариях. - СПб.: Питер, 2005.

[3] Анцупов А.Я., Шапилов А.И. Трудне ситуации в жизнедеятельности человека // Психология конфликта. - СПб.: Питер, 2001. C. 269-274.

[4] Гришина Н.В. Психология конфликта.-СПб.: Питер, 2005.

[5] Дойч $M$. Конструктивное разрешение конфликта: принципы, обучение и исследования // Психология конфликта. - СПб.: Питер, 2001. - C. $173-198$.

[6] Донцов А.И. Психология коллектива. - М., 1984.-С. 141-149.

[7] Емельянов C.M. Практикум по конфликтологии. - СПб.: Питер, 2004.

[8] Козырев Г.И. Введение в конфликтологию.-М.: Владос, 2001.

[9] Кричевский Р.Л., Дубовская Е.М. Межличностный конфликт // Психология конфликта. - СПб.: Питер, 2001. - С. 371-379.

[10] Кричевский Р.Л., Дубровская Е.М. Психология малой группы: теоретический и прикладной аспекты. - М., 1991. - С. 145-152.

[11] Кэмпбелл Д. Реалистическая теория межгруппового конфликта // Психология конфликта. - СПб.: Питер, 2001. - С. 410-415. 